\title{
Evaluation of udder health in relation to enzymatic changes in milk of Non-Descript sheep of Buldhana District
}

\author{
Sapana S. Paithane, Mohini.V. Khodke \\ Department of Veterinary Biochemistry Post Graduate Institute of Veterinary and Animal Sciences, Akola
}

\begin{abstract}
The present experiment was conducted to study variations in milk Somatic Cell Count( SCC), $p H$ and activity of whey enzyme Lactate Dehydrogenase $(L D H)$ in relation to different udder health status of sheep. The average values of milk SCC, $p H$, and LDH differed significantly $(P<0.01)$ among various udder health status of sheep. The mean difference for SCC of milk showed significant $(P<0.01)$ differences varying from 2.89 to $35.45 \times 10^{5}$. The average milk $p H$ values ranged from $6.44 \pm 0.006$ to $7.22 \pm 0.03$. Also, LDH showed significant $(P<0.01)$ differences among various udder health status of sheep.
\end{abstract}

Keywords: Lactate dehydrogenase, $\mathrm{pH}$, Sheep, Somatic Cell Count.

\section{Introduction}

India ranks sixth among the countries of the world in respect to sheep population. Sheep milk is relished and consumed more as compared to the milk from goats. About two per cent of the total milk consumed by the human population is from sheep (Gatenby, 1986). In Western countries sheep milk is also processesed for preparation of cheese and milk products (Pulina et al., 1996). The udder health is closely related to the milk production of the animal. And ill health of the udder was ascribed to decrease the milk production upto $55 \%$ in ewes (Saratsis et al. 1999). Udder health status particularly, of ewes has received a very limited scientific attention. Health of the udder not only alters the nutritional quality but also changes the biochemical profile of milk, affecting thereby the health of consumers, both lambs and human beings (Kalinowska, 1990). In the recent years, although attention has been given for the diagnosis of subclinical mastitis by direct test like California Mastitis Test (CMT), however, their accuracy and sensitivity vary from person to person. Milk of normal healthy sheep contains a wide variety of enzymes. These enzymes are secreted by the epithelial cells of mammary gland. In mastitis, muscle and tissues of mammary gland are damaged which may lead to increase in the release of these enzymes in milk (Kitchen et al., 1970).

\section{Materials And Methods}

The present investigation was carried out in the Department of Veterinary Biochemistry, at the Post Graduate Institute of Veterinary Sciences (PGIVAS), Akola. The study comprised of 170 milk samples from normal, subclinical and clinical mastitic quarters of sheep of Khamgoan district.

Table-1: Category-wise milk sample on the basis of clinical examination of udder and CMT reaction

\begin{tabular}{|c|c|c|c|c|}
\hline \multirow[t]{2}{*}{ Group } & $\begin{array}{l}\text { Number of } \mathrm{CMT} \\
\text { negative milk sample }\end{array}$ & $\begin{array}{l}\text { Number of CMT positive } \\
\text { milk sample }\end{array}$ & $\begin{array}{l}\text { Number of clinical mastitic } \\
\text { milk samples }\end{array}$ & \multirow[t]{2}{*}{ Total } \\
\hline & Normal & Subclinical & Clinical & \\
\hline No. Of halves & 12 & $\begin{array}{lll}1+ & 2+ & 3+ \\
12 & 12 & 12\end{array}$ & 12 & 60 \\
\hline No. Of Sheep & 12 & 12 & 12 & 60 \\
\hline
\end{tabular}

collected after thorough clinical examination of udder. For each freshly collected milk samples, the $\mathrm{pH}$ was measured using a digital $\mathrm{pH}$ meter (E.I. Model 101E).Following staining, SCC estimation done by the method in accordance with Schalm et al. (1971). Whey was prepared by method given by Olson et al. 1981. The activity of LDH in whey was estimated by using the laboratory made reagents as per the spectrophotometric method of Oser (1965). The optical optical densities were read on a double beam systronic spectrophotometer at $520 \mathrm{~nm}$. Standard statistical procedures like, completely randomized design, mean, standard error and regression coefficient laid down by Snedecor and Cochrane (1994).

\section{Results And Discussion}

Estimation of somatic cell count and $\mathrm{pH}$ in milk along with whey LDH obtained from healthy and mastitic quarters of sheep, generated a sizable data, which were statistically analyzed to interpret the results.

Somatic cell count: The averages of SCC of milk with their standard errors for comparisons in different udder health status of sheep are presented in Table 2. The results indicated an increase in number of SCC of milk with the increase in severity of mastitis. The statistical analysis of variance of the data generated for the average SCC 
of sheep milk indicated an increasing trend from normal to clinical mastitic groups (Table 3). The SCC is an indicator of the intensity of the cellular immune defense and it represents a marker of the sanitary state of the udder. During the course of intramammary infection, leucocytes migrate from the blood towards the mammary gland leading to increase somatic cells in the milk. SCC represents a valuable tool for prevalence assessment and screening mastitis (Gonzalo et al., 2002). The multiple factors (pathogens, toxins, mechanical damage to tissues) physiological factors (age, lactation stage) and pharmacological factors (different drugs) and stress factors (change in feeding, transport) and management factors were reported to affect SCC of milk (Heeschen, 1996).

Table-2: Mean and standard error for somatic cell count, $\mathrm{pH}$ and $\mathrm{LDH}$ of milk in different udder health status of

\begin{tabular}{|l|l|l|l|l|l|}
\hline \multicolumn{2}{|c|}{ Udder health status } & \multirow{2}{*}{ Normal milk } & Subclinical & \multirow{2}{*}{ Clinical } \\
\cline { 3 - 6 } & & $1+$ & $2+$ & $3+$ & \\
\hline SCC $\left(\mathrm{x} \mathrm{10} 0^{5}\right.$ cells/ml $)$ & $2.89 \pm 0.03$ & $6.59 \pm 0.03$ & $15.33 \pm 0.07$ & $20.54 \pm 0.14$ & $35.45 \pm 0.17$ \\
\hline pH & $6.44 \pm 0.006$ & $6.5 \pm 0.44$ & $6.62 \pm 0.37$ & $6.85 \pm 0.30$ & $7.22 \pm 0.03$ \\
\hline LDH & $515.94 \pm 2.89$ & $674.3 \pm 4.52$ & $722.57 \pm 2.41$ & $931.99 \pm 2.60$ & $1222.43 \pm 4.47$ \\
\hline
\end{tabular}

Different superscripts indicate significance between udder health statuses

pH: The averages of $\mathrm{pH}$ of milk with their standard errors for comparisons in different udder health status of sheep are presented in Table 2. The results indicated an increase in $\mathrm{pH}$ of milk with the increase in severity of mastitis.The $\mathrm{pH}$ values for normal group ranging between 6.4 to 6.49 with a mean of $6.44 \pm 0.006$.The statistical analysis of variance of the data generated for the average $\mathrm{pH}$ of sheep milk indicated an increasing trend from normal to clinical mastitic groups (Table 3). Rao (1990) reported that the inflammation of the udder may be responsible for the increased permeability of mammary gland to the components of blood, particularly bicarbonates and other alkaline salts into the milk together with the decreased production of lactose by the gland; so that the milk pH became above 7.0.

Lactate dehydrogenase: The averages of $\mathrm{pH}$ of milk with their standard errors for comparisons in different udder health status of sheep are presented in Table 2. The results indicated an increase in LDH of milk with the increase in severity of mastitis.And the same increasing trend of LDH activity with the increase in the severity of mastitis was observed by Banga et al. (1989), in sheep milk-whey. The statistical analysis of variance of the data generated for the average $\mathrm{pH}$ of sheep milk indicated an increasing trend from normal to clinical mastitic groups (Table 3). Kitchen et al.(1970) reported that in mastitis, the release of various enzymes into body fluid was from damaged tissue or inflammed cell. Bogin and Ziv (1973) have suggested that LDH in milk was sensitive indicator of epithelial cell damage and subsequently proposed that increased LDH activity in mastitic milk was reported to be caused by the liberation from parenchyma cells of udder and disintegrating leukocytes or both and from other sources like, serum.

Tablr-3: Analysis of variance for SCC, $\mathrm{pH}$ and LDH of milk

\begin{tabular}{|l|l|l|l|l|}
\hline Parameters & Source of variation & Degree of freedom & MSS & Fcal \\
\hline SCC & Udder health status & 4 & 1.234 & $318.837 * *$ \\
\hline pH & Udder health status & 4 & 1952.683 & $13933.629 * *$ \\
\hline LDH & Udder health status & 4 & 892355.075 & $6045.839 * *$ \\
\hline
\end{tabular}

$* *=$ significant at $1 \%$ level

\section{Conclusion}

The statistical analysis and interpretation of data led to conclusions that the somatic cell count of milk can be used as reliable indicator of diagnostic importance for clinical and subclinical conditions of udder inflammation in sheep. The alterations in the somatic cell count of milk, activity of LDH in milk whey are proportional to the severity of the udder infection as detected by CMT reaction.

\section{References}

[1]. Banga, H. S., P. P. Gupta, S. P. Ahuja, A. K. Srivstava and K. S. Roy. Biochemical alterations in the blood, milk and tissues of sheep mammary gland after experimental mycoplasmal mastitis. Acta Vet. BRNO, 58, 1989: 97-111.

[2]. Bogin, E. and G. Ziv, (1973). Enzymes and minerals in normal and mastitis milk. Cornell vet. 63 : 666-676.

[3]. Gatenby, R. M. ,(1986) : Sheep production in the tropics and sub-tropics. $1^{\text {st }}$ Edn. New York, Longman Inc.

[4]. Gonzalo, C., A, Ariznabarreta, J. A. Carriedo, F. San Primitivo, (2002), Mammary pathogens and their relationship to somatic cell count and milk yield losses in dairy ewes. Journal of Dairy Science, 85: 1460-1467.

[5]. Heeschen, W. (1996). Influence of mastitis on quality and hygiene characteristics of milk. Praktische Tierartz. 77 (3) : $223-226$. (Abst. Dairy Sci., $59: 1005)$

[6]. Kalinowska, C., (1990) : The effect of mastitis in merino-ewe on body weight and mortality rate of lambs. Dairy Sci. Abstr. $\mathbf{5 5}$ (4) : 296.

[7]. Kitchen, B. J., G. C. Taylor and I. C. White (1970). Milk enzymes, their distribution and activity. J. Dairy Res., 37 : $279-288$. 
[8]. Olson, D. P.., R. C. Bull, L. F. Woodard and K. E. Kelly (1981). Effects of maternal nutritional restriction and cold stress on young calves. Absorption of Colostral Immunoglobulins. Am. J. Vet. Res. 42 : 876-880.

[9]. Oser, B. L. (1965). Blood analysis in : Hawk's physiological chemistry. $14^{\text {th }}$ Ed $^{\text {n }}$. The Blackston Division, McGraw Hill Book Co, New York. Pp. 95-1152.

[10]. Pulina, G., A. Nudda., C. Casolic, D. E. Ranucis, M. Molgahte and L. Campus, (1996) : Factors responsible for the decrease in cheese making quality of ewe milk. Dairy Sci. Abstr. 59 (4) : 269.

[11]. Rao, K.S.R. (1990) : Milk formation - Alteration in mastitic milk composition. Ind. Dairyman 42(7) : $314-316$.

[12]. Saratsis, P., C. Alexopoulos, A. Tzora, and G. C. Fthenakis, (1999) : The effect of experimentally induced subclinical mastitis on the milk yield of dairy ewes. Small ruminant Res. 32 (3) : 205-209.

[13]. Schalm, O. W., G. Caroll and N. C. Jain (1971). Bovine Mastitis; Lea and Febriger Philadelphia Pa, USA: pp.95-127.

[14]. Snedecor,W. and W. G. Cochran (1994). Statistical Methods. $8^{\text {th }}$ Ed $^{\text {n }}$, EastWest Press Pvt Ltd., new Delhi.

[15]. (This paper has sent to ISOR journal on dated 19 october 2016) 